\title{
Teori Kewirausahaan Ketidaksetujuan Strategis: Spinout untuk Wirausaha Baru
}

\author{
Agung Purnomo \\ Program Studi Kewirausahaan \\ Universitas Bina Nusantara \\ agung.purnomo@binus.ac.id
}

Kajian studi kewirausahaan di bumi Indonesia semakin tumbuh dan berkembang (Purnomo et al., 2019). Kewirausahaan (entrepreneurship) merupakan suatu sikap kemampuan, jiwa, dan mental yang selalu aktif guna mengkreasi hal baru yang sangat berguna dan bernilai bagi orang lain, diri, serta meningkatkan pendapatan (Hastuti et al., 2020). Untuk memahami dan mengembangkan pengetahuan kewirausahaan, para peneliti dan pemikir melakukan studi dan mengembangkan beberapa teori kewirausahaan.

Salah satu teori kewirausahaan yang berkembang adalah teori kewirausahaan ketidaksetujuan strategis (the strategic disagreements theory of entrepreneurship) yang digagas oleh Steven Klepper. Klepper adalah seorang ekonom Amerika di Universitas Carnegie Mellon. Klepper memperkenalkan konsep ketidaksepakatan strategis pada wirausaha yang digunakan untuk menjelaskan jenis kewirausahaan tertentu yang biasa disebut sebagai kewirausahaan spinoff (spinoff entrepreneurship) atau spinout karyawan (employee spinout) (Klepper, 2007; Klepper \& Thompson, 2010).

Spinoff atau corporate spinoff adalah hasil dari manajer perusahaan induk memutuskan untuk membuat divisi atau anak perusahaan menjadi badan hukum terpisah dengan pemilik yang berbeda meskipun sering tumpang tindih. Spinoff sering digunakan untuk meningkatkan koherensi perusahaan dan memberikan usaha baru kemandirian yang mereka butuhkan untuk berkembang (Agarwal et al., 2007).

Spinout atau employee spinout adalah hasil dari keputusan independen karyawan yang meninggalkan perusahaan induk untuk memulai usaha baru. Baik perusahaan induk maupun investor tidak menerima saham kepemilikan dalam spinout karena spinout biasanya dimiliki dan dikendalikan oleh mantan karyawan dan investor mereka sendiri seperti pemodal ventura. Karena mereka manajer dan perusahaan induk tidak berwenang, spinout sering kali mendapat permusuhan dari manajer dan pemilik perusahaan induk (Walter et al., 2014).

Klepper memuji spinout dengan pembuatan klaster wirausaha pemula di negara Amerika seperti Silicon Valley dan Detroit. Spinout terjadi ketika seorang karyawan sebuah perusahaan pergi untuk memulai bisnis baru. Sebagian besar pengusaha spinout menciptakan usaha yang bersaing secara tidak langsung dengan pemberi kerja 
mereka dengan mengejar strategi baru atau mengejar pasar baru dengan produk yang berbeda (Klepper, 2007). Namun, benih usaha spinoff sering kali juga berasal dari perusahaan induk. Misalnya, banyak pengusaha melaporkan bahwa mereka mengeksploitasi ide-ide yang dihasilkan di dalam organisasi tempat kerja mereka sebelumnya (Bhide, 1994).

Teori ketidaksepakatan strategis mengacu pada ketidaksepakatan antara karyawan dan manajer mengenai prospek ide baru atau proyek baru. Misalnya, seorang karyawan mungkin percaya bahwa perusahaan harus mengejar teknologi baru tetapi manajemen perusahaan dapat memilih untuk tidak melakukannya (Thompson $\&$ Chen, 2011). Sebaliknya, manajemen perusahaan dapat memilih untuk mengeksploitasi teknologi baru tetapi karyawan tersebut mungkin tidak ingin melakukannya. Karena, perusahaan percaya bahwa eksploitasi berkelanjutan dari teknologi saat ini lebih efisien atau efektif. Jenis ketidaksepakatan ini mendorong karyawan untuk keluar untuk memulai usaha mereka sendiri (Laplume \& Yeganegi, 2018).

Ketidaksepakatan strategis dipandang sebagai hal yang tak terhindarkan karena perusahaan sering kali menghasilkan lebih banyak ide daripada yang dapat mereka eksploitasi. Perusahaan yang mempersempit strategi mereka dan mendorong karyawan mereka untuk mengeksplorasi di dalamnya dapat menghasilkan lebih sedikit spinoff. Ada juga perusahaan yang lebih terdiversifikasi untuk mendorong pencarian ide dan proyek yang terlalu luas yang dapat melipatgandakan potensi ketidaksepakatan strategis (Stieglitz \& Heine, 2007).

\section{Referensi}

Agarwal, R., Audretsch, D., \& Sarkar, M. B. (2007). The process of creative construction: knowledge spillovers, entrepreneurship, and economic growth. Strategic Entrepreneurship Journal, 1(3-4), 263-286. https://doi.org/10.1002/sej.36

Hastuti, P., Nurofik, A., Purnomo, A., Hasibuan, A., Aribowo, H., Faried, A. I., Tasnim, T., Sudarso, A., Soetijono, I. K., Saputra, D. H., \& Simarmata, J. (2020). Kewirausahaan dan UMKM. Yayasan Kita Menulis. https://kitamenulis.id/2020/03/02/kewirausahaan-dan-umkm/

Klepper, S. (2007). Disagreements, Spinoffs, and the Evolution of Detroit as the Capital of the U.S. Automobile Industry. Management Science, 53(4), 616-631. https://doi.org/10.1287/mnsc.1060.0683

Klepper, S., \& Thompson, P. (2010). Disagreements and intra-industry spinoffs. International Journal of Industrial Organization, 28(5), 526-538.

https://doi.org/10.1016/j.ijindorg.2010.01.002

Laplume, A., \& Yeganegi, S. (2018). Strategic Disagreements and Entrepreneurship. Entrepreneurship Theories. https://entrepreneurshiptheories.blogspot.com/2017/08/strategic- 
disagreements-theory.html

Purnomo, A., Usman, I., \& Asitah, N. (2019). Penelitian Kewirausahaan di Indonesia: Pemetaan Publikasi dalam Perspektif Scientometrik (1972-2019). AdBispreneur, 4(3), 207. https://doi.org/10.24198/adbispreneur.v4i3.25021

Stieglitz, N., \& Heine, K. (2007). Innovations and the role of complementarities in a strategic theory of the firm. Strategic Management Journal, 28(1), 1-15. https://doi.org/10.1002/smj.565

Thompson, P., \& Chen, J. (2011). Disagreements, employee spinoffs and the choice of technology. Review of Economic Dynamics, 14(3), 455-474. https://doi.org/10.1016/j.red.2010.09.003

Walter, S. G., Heinrichs, S., \& Walter, A. (2014). Parent hostility and spin-out performance. Strategic Management Journal, 35(13), 2031-2042. https://doi.org/10.1002/smj.2201 